\title{
Comparison of Soft Tissue Cephalometric Parameters Distinguishing Skeletal Class I, II and III Malocclusion
}

Maria Habib ${ }^{1}$

Tabassum Ahsan ${ }^{2}$

Omair Majeed $^{3}$

Mazia Jawaid $^{4}$
BDS

BDS, FCPS

BDS

BDS

OBJECTIVE: The present study assess some cephalometric measurements of the soft tissue profile in order to observe the behavior of facial convexity in patients with Class I, Class II division 1, and Class III malocclusions.

METHODOLOGY: 102 Pre-treatment cephalometric radiographs of patients attending orthodontic OPD. Ages 16-45 years (mean age of 17.6 years) were selected for this study. They were divided into 3 groups, Class I, class II and class III, using ANB value of (Steiners analysis). Soft tissue cephalometric values of angle of convexity, H.SN angle, nasolabial angle, mentolabial angle and linear measurements of upper and lower lip to S line was measured by a single observer. Inter group and inter gender comparison of all the variable were done.

RESULTS: The result showed significant differences amongst the three groups in mentolabial angle , H.SN angle, upper lip to $\mathrm{S}$ line and lower lip to $\mathrm{S}$ lines.

KEY WORDS: Cephalometry, Coft tissue profile, Casolabial angle.

HOW TO CITE: Habib M, Ahsan T, Majeed O, Jawaid M. Comparison of soft tissue cephalometric parameters distinguishing skeletal class I, II and III malocclusion. J Pak Dent Assoc 2020;29(1):14-18.

DOI: https://doi.org/10.25301/JPDA.291.14

Received: 16 May 2019, Accepted: 19 September 2019

\section{INTRODUCTION}

$\mathrm{M}$ odern treatment goals and limitations of orthodontic and orthognathic surgery are dictated by the soft tissue paradigm. ${ }^{1}$ It dictates that treatment goals, diagnostic emphasis and treatment approach when governed by soft tissues of the face will lead to a normal teeth and jaw relationship. ${ }^{2}$ The shift of orthodontics away from the conventional angles paradigm has provided a new direction to the field of orthodontics in general and also specifically to our primary goal of preserving, or achieving optimal facial attractiveness. For this purpose it is important that orthodontists conduct a thorough examination, for identification of areas of disharmony and have a thorough knowledge of how their treatment would affect the patient's facial profile.

The importance of identifying the facial types of each

1. Senior Lecturer, Department of Orthodontics, Bahria University Medical and Dental College.

2. Associate Professor Head of Department, Department of Orthodontics, Bahria University Medical and Dental College.

3. Senior Lecturer, Department of Orthodontics, Bahria University Medical and Dental College.

4. Registrar, Department of Orthodontics, Bahria University Medical and Dental College.

Corresponding author: "Dr. Maria Habib" < mrsfurrukh@gmail.com > individual arises from the influence it has on the profile of the individual and dental arches. ${ }^{3}$ The affects that incisor positions have on their respective bony bases and resultant facial patterns has also been the topic of many researches. ${ }^{4}$

Facial profile comprises of several skeletal, dental and facial components, and each has to be in a normal range for a normal facial profile. Multiple factors include the positions of dentition, skeletal problems, along with growth which also plays a major role in the development of soft tissue profile of an individual. Knowledge of the soft tissue profile changes at different stages of growth would allow the operator to treat those variations in values as normal for a specific age. For example studies have found that during youth there is more extensive growth in the area of nose and lips where as there is minimal growth in the menton area. Upper lip full length is established by the age of 7, increase in depth and length of the nose is observed in adult's facial profile for both genders. In men, the upper and lower lip thickness diminishes, whereas in women the profile becomes more convex because there are greater growth changes in the nose than in the menton. ${ }^{3}$

Different malocclusions therefore have a specific set of values for each of these variables, and it is of utmost importance that the orthodontist is aware of these values 
before starting the treatment. The lip position can be evaluated by various reference lines such as Steiner S-line ${ }^{5}$, Burstone's B line ${ }^{6}$, Rickets E line ${ }^{7}$, Holdaway H line. ${ }^{8}$

Our study aims to assess the cephalometric measurements of soft tissue profile in patients of class I, II and III, malocclusions to specify the soft tissue patterns for those malocclusions. Based on this knowledge the treatment plans can be better devised for the patients. This study will also help to clarify if soft tissue analysis alone can be used to asses skeletal malocclusions.

\section{METHODOLOGY}

\section{Methodology and data collection}

It was a cross sectional study, using 102(sample size calculated by open-epi software ${ }^{19}$ ) pretreatment cephalometric radiographs of patients attending orthodontic OPD. Ages 16-45 years (mean age of 17.6 years) were selected for this study to ensure completion of growth of soft and hard tissue.

The cephalometric radiograph was obtained by one digital machine, model Viata Pano with a power input of $200-240 \mathrm{~V}, 50 / 60 \mathrm{~Hz}$ and $2.2 \mathrm{Kva} \max$.

They sample was divided into 3 groups, Class I, class II and class III( using ANB value of (Steiners analysis). Sample size calculation was done using open-epi soft ware, with the confidence interval kept $95 \%$. These $\mathrm{x}$ rays are a

\section{Figure 1}

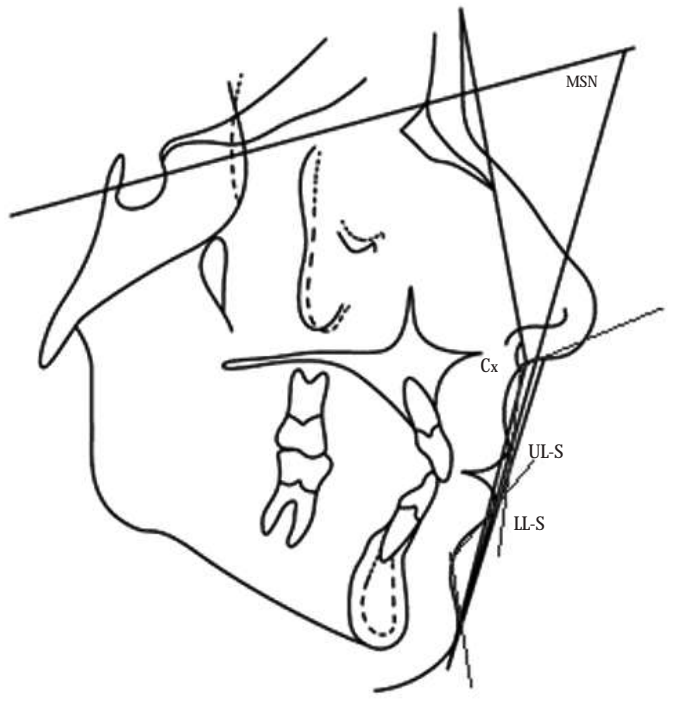

part of usual diagnostic protocol of orthodontic cases, therefore no ethical concern was applicable. An informed consent was taken from all patients at the start of treatment informing them that their records would be utilized for research purposes. All radiographs were traced on an acetate
Table 1

\begin{tabular}{|c|c|}
\hline VARIABLES & DEFINITION \\
\hline $\begin{array}{l}\text { ANGLE OF FACIAL CONVEXITY } \\
\text { (CX) }\end{array}$ & $\begin{array}{l}\text { Formed by the intersection of the line that passes through the } \\
\text { glabella point }\left(G^{\prime}\right) \text { and the subnasale point ( }(\mathrm{n}) \text { )and another line } \\
\text { from the subnasale point tothe soft pogonion point }\left(\text { Pog }^{\prime}\right) \text {. Ideally } \\
\text { it should be }-11 \pm 4^{\circ} \text { according to Downs }\end{array}$ \\
\hline ANGLE (H.SN) & $\begin{array}{l}\text { Formed by the intersection of SNline with } \mathrm{H} \text {-line. For Holdaway } \\
\text { and Merrifield the value of this angle should be } 73^{\mathrm{in}}\end{array}$ \\
\hline NASOLABIAL ANGLE (NLA) & $\begin{array}{l}\text { Formed by the intersection of the line that passes through the } \\
\text { columella }(\mathrm{Cm}) \text { and subnasal }(\mathrm{Sn}) \text { points and the line that passes } \\
\text { through the labrale superior (Ls)and subnasale ( } \mathrm{Sn} \text { ) points. } \\
\text { According to Sheideman } \\
\text { with a clinical deviation from nasolabial angle must beat } 110^{\circ} \text { to } 110^{\circ}\end{array}$ \\
\hline MENTOLABIAL ANGLE (MLA) & $\begin{array}{l}\text { Formed by the intersection of the line that passes through the the } \\
\text { lower lip vermillion point (LV) up to point } \mathrm{B}^{\prime} \text { and a line from point } \\
\mathrm{B}^{\prime} \text { to the soft pogonion point (Pog') which, according to Nguyen } \\
\text { and Turley" must be to } 128.5^{\circ} \text { with a clinical deviation of } \pm 11^{\circ} \text {. }\end{array}$ \\
\hline UPPERLIP - S-UINE & $\begin{array}{l}\text { Distance from the most anterior point of the upper lip convexity } \\
\text { to the S-line of Steiner. } \\
\text { would be } 0 \mathrm{~mm}\end{array}$ \\
\hline LOWERLIP - S-LINE & $\begin{array}{l}\text { Distance from the most anterior point of the lower lip convexity to } \\
\text { S-line of Steiner }{ }^{5} \text {. According to Steiner the ideal distance would } \\
\text { also be } 0 \mathrm{~mm} \text {. }\end{array}$ \\
\hline
\end{tabular}

Diagrammatically shown in figure 1.

paper with a lead pencil by the same observer to reduce intra-examiner variablilty, reading as given in figure 1 were traced and values were calculated.

The participants in the sample were randomly selected with convenience sampling. Only those cases were included who had never undergone any orthodontic treatment before. Cases having a crossbite or open bite were excluded along with syndromic patients and those who needed orthognathic surgery as their treatment plan.

Data analysis was performed using the SPSS version 23. The analysis of variance and turkey hoc test (table.3, table.4) was used for the comparative analysis of the variables between the three groups of malocclusion. Independent sample t test was used to compare between two genders.

\section{RESULT}

The result showed significant differences amongst the three groups in mentolabial angle, H.SN angle, upper lip to $\mathrm{S}$ line and lower lip to $\mathrm{S}$ lines as shown in table 2. Mentolabial angle was highest in class $2\left(122.46^{\circ}\right)$ and a lowest in class III group $\left(106.96^{\circ}\right), \mathrm{H}$.SN angle is class III group was highest value of $67.12^{\circ}$ and a lowest value of $58.23^{\circ}$ in class 2 group. Upper lip and lower lip to S-line was highest in class 2 groups and lowest in class III group, $2.187 \mathrm{~mm}, 2.500 \mathrm{~mm}$ and $-2.20 \mathrm{~mm}, 0.55 \mathrm{~mm}$ respectively. The comparative analysis between all variables in the three groups is shown in bar chart (figure 2). Comparison between male and female groups showed significant differences in nasolabial angle and upper lip to $\mathrm{S}$ line. Nasolabial angle was a mean of $104.50^{\circ}$ in males and $98.76^{\circ}$ in females. According to descriptive analysis the mean value of angle of convexity came out to be $31.40^{\circ}$, with class 1 group having the highest value of $33.03^{\circ}$, and a lowest value in 
Table 2: Independent samples test Levene's Test t-test for Equality of Means for Equality F Sig. t df Sig. Mean Std. Error $95 \%$ confidence (2. Difference Difference interval \begin{tabular}{lllllllllll}
\hline ANGLE OF & Equal & 0.093 & 0.762 & 1.882 & 100 & 0.063 & 4.250 & 2.259 & -0.231 & 8.731
\end{tabular} CONVEXITY variances $\begin{array}{llllllll}\text { assumed } & 1.973 & 75.016 & 0.052 & 4.250 & 2.155 & -0.042 & 8.542\end{array}$ Equal variances
not not

\begin{tabular}{lllllllllll}
\hline H.SN ANGLE & Equal & 0.313 & 0.577 & -0.452 & 100 & 0.652 & -0.882 & 1.951 & -4.754 & 2.989
\end{tabular} variances \begin{tabular}{llllllll}
\hline Equal & -0.430 & 58.082 & 0.669 & -0.882 & 2.051 & -4.988 & 3.224
\end{tabular} variances not

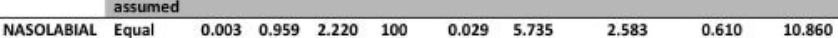

ANGLE, variances

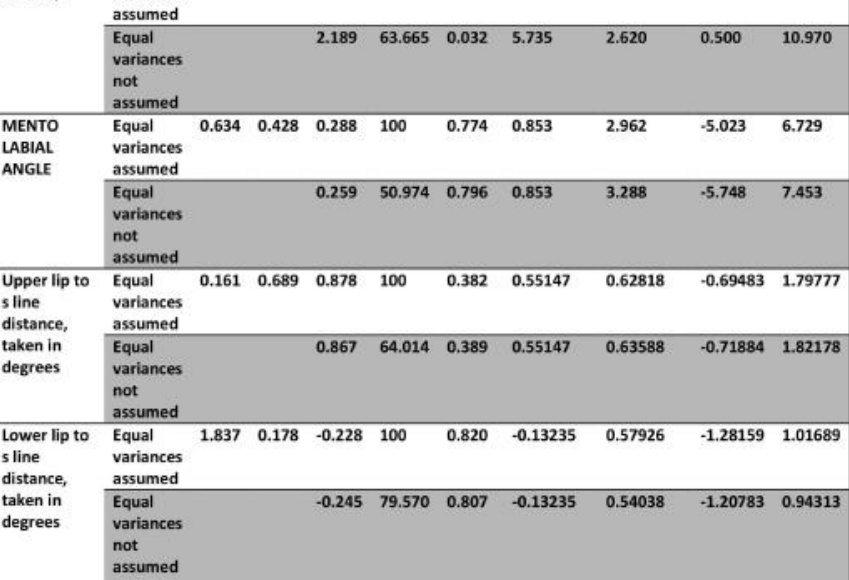

\begin{tabular}{|c|c|c|c|c|c|c|}
\hline & & $\begin{array}{l}\text { Sum of } \\
\text { Squares }\end{array}$ & & $\begin{array}{l}\text { Mean } \\
\text { Square }\end{array}$ & $\mathrm{F}$ & Sig. \\
\hline \multirow[t]{3}{*}{ ANGLE OF CONVEXITY } & $\begin{array}{l}\text { Between } \\
\text { Groups }\end{array}$ & 136.605 & 2 & 68.303 & 0.571 & 0.567 \\
\hline & $\begin{array}{l}\text { Within } \\
\text { Groups }\end{array}$ & 11835.914 & 99 & 119.555 & & \\
\hline & Total & 11972.520 & 101 & & & \\
\hline \multirow[t]{3}{*}{ H.SN ANGLE } & $\begin{array}{l}\text { Between } \\
\text { Groups }\end{array}$ & 1386.310 & 2 & 693.155 & 9.450 & 0.000 \\
\hline & $\begin{array}{l}\text { Within } \\
\text { Groups }\end{array}$ & 7261.337 & 99 & 73.347 & & \\
\hline & Total & 8647.647 & 101 & & & \\
\hline \multirow[t]{3}{*}{ NASOLABIAL ANGLE } & $\begin{array}{l}\text { Between } \\
\text { Groups }\end{array}$ & 13.148 & 2 & 6.574 & 0.041 & 0.960 \\
\hline & $\begin{array}{l}\text { Within } \\
\text { Groups }\end{array}$ & 15857.176 & 99 & 160.173 & & \\
\hline & Total & 15870.324 & 101 & & & \\
\hline \multirow[t]{3}{*}{ MENTO LABIAL ANGLE, } & $\begin{array}{l}\text { Between } \\
\text { Groups }\end{array}$ & 4164.717 & 2 & 2082.359 & 13.104 & 0.000 \\
\hline & $\begin{array}{l}\text { Within } \\
\text { Groups }\end{array}$ & 15732.626 & 99 & 158.915 & & \\
\hline & Total & 19897.343 & 101 & & & \\
\hline \multirow[t]{3}{*}{ UPPER LIP TO S LINE } & $\begin{array}{l}\text { Between } \\
\text { Groups }\end{array}$ & 345.206 & 2 & 172.603 & 30.725 & 0.000 \\
\hline & $\begin{array}{l}\text { Within } \\
\text { Groups }\end{array}$ & 556.147 & 99 & 5.618 & & \\
\hline & Total & 901.353 & 101 & & & \\
\hline \multirow[t]{3}{*}{ LOWER LIP TO S LINE } & $\begin{array}{l}\text { Between } \\
\text { Groups }\end{array}$ & 66.672 & 2 & 33.336 & 4.753 & 0.011 \\
\hline & $\begin{array}{l}\text { Within } \\
\text { Groups }\end{array}$ & 694.291 & 99 & 7.013 & & \\
\hline & Total & 760.963 & 101 & & & \\
\hline
\end{tabular}

class III of $30.39^{\circ}$. Nasiolabial was a $100.68^{\circ}$ with highest value in class 1 group $\left(101.12^{\circ}\right)$ and lowest in class III group (100.22).
Figure 2

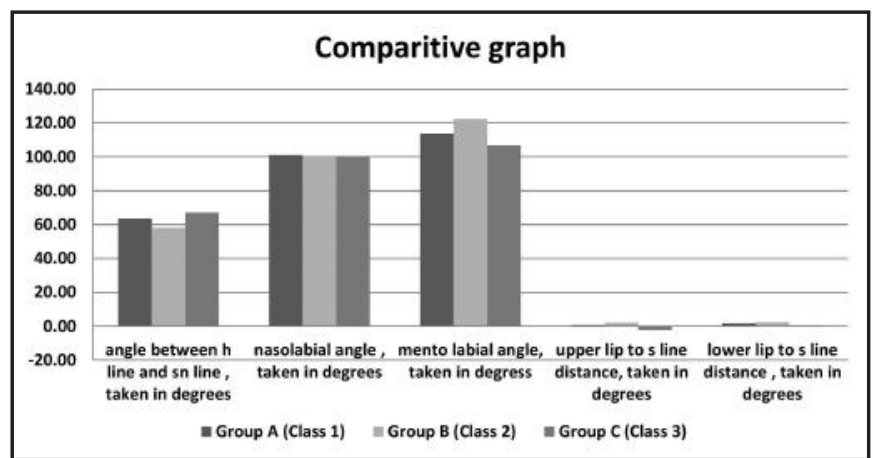

\begin{tabular}{|c|c|c|c|c|c|c|c|}
\hline \multicolumn{8}{|c|}{ TUKEY HSD } \\
\hline \multirow[t]{2}{*}{$\begin{array}{l}\text { Dependent } \\
\text { Variable }\end{array}$} & \multirow[t]{2}{*}{ (1) skeletal dsss } & \multirow[t]{2}{*}{ (J) skeletal dsss } & \multirow{2}{*}{$\begin{array}{l}\text { Mean } \\
\text { Difference } \\
(1-J)\end{array}$} & \multirow[t]{2}{*}{ Std. Error } & \multirow[t]{2}{*}{ Sig. } & \multicolumn{2}{|c|}{$\begin{array}{l}\text { 95\% Confidence } \\
\text { Interval }\end{array}$} \\
\hline & & & & & & $\begin{array}{l}\text { Lower } \\
\text { Bound }\end{array}$ & $\begin{array}{l}\text { Upper } \\
\text { Bound }\end{array}$ \\
\hline \multirow[t]{6}{*}{ ANB angle } & \multirow{2}{*}{ Group A (Class 1) } & Group B (Class 2) & $-3.322^{\circ}$ & .561 & .000 & -4.66 & -1.99 \\
\hline & & Group C(Class 3) & 7.217 & .565 & .000 & 5.87 & 8.56 \\
\hline & \multirow[t]{2}{*}{ Group B (Class 2) } & Group A (Class 1) & $3.322^{\circ}$ & .561 & .000 & 1.99 & 4.66 \\
\hline & & Group C (Class 3) & $10.539^{\circ}$ & .557 & .000 & 9.21 & 11.86 \\
\hline & \multirow[t]{2}{*}{ Group C (Class 3) } & Group A (Class 1) & -7.217 & .565 & .000 & -8.56 & -5.87 \\
\hline & & Group B (Class 2) & $-10.539^{\circ}$ & .557 & .000 & -11.86 & -9.21 \\
\hline \multirow[t]{6}{*}{ chronological age } & \multirow[t]{2}{*}{ Group A (Class 1) } & Group B (Class 2) & 1.880 & 1.211 & .271 & -1.00 & 4.76 \\
\hline & & Group C(Class 3) & 1.982 & 1.219 & .240 & -.92 & 4.88 \\
\hline & \multirow[t]{2}{*}{ Group B (Class 2) } & Group A (Class 1) & -1.880 & 1.211 & .271 & -4.76 & 1.00 \\
\hline & & Group C(Class 3) & .103 & 1.202 & .996 & -2.76 & 2.96 \\
\hline & \multirow[t]{2}{*}{ Group C (Class 3) } & Group A (Class 1) & -1.982 & 1.219 & .240 & -4.88 & .92 \\
\hline & & Group B (Class 2) & -103 & 1.202 & .996 & -2.96 & 2.76 \\
\hline \multirow[t]{6}{*}{ angle of convexity } & \multirow[t]{2}{*}{ Group A (Class 1) } & Group B (Class 2) & 2.087 & 2.653 & .712 & -4.23 & 8.40 \\
\hline & & Group C (Class 3) & 2.736 & 2.672 & .564 & -3.62 & 9.09 \\
\hline & \multirow{2}{*}{ Group B (Class 2) } & Group A (Class 1) & -2.087 & 2.653 & .712 & -8.40 & 4.23 \\
\hline & & Group C(Class 3) & .649 & 2.633 & .967 & -5.62 & 6.91 \\
\hline & \multirow[t]{2}{*}{ Group C (Class 3) } & Group A (Class 1) & -2.736 & 2.672 & .564 & -9.09 & 3.62 \\
\hline & & Group B (Class 2) & .649 & 2.633 & .967 & -6.91 & 5.62 \\
\hline \multirow{6}{*}{$\begin{array}{l}\text { angle between h } \\
\text { line and sn line, }\end{array}$} & \multirow[t]{2}{*}{ Group A (Class 1) } & Group B (Class 2) & $5.408^{\circ}$ & 2.078 & .029 & .46 & 10.35 \\
\hline & & Group C (Class 3) & -3.481 & 2.093 & .224 & -8.46 & 1.50 \\
\hline & \multirow[t]{2}{*}{ Group B (Class 2) } & Group A (Class 1) & $-5.408^{\prime}$ & 2.078 & .029 & -10.35 & .46 \\
\hline & & Group C (Class 3) & $8.889^{\circ}$ & 2.062 & .000 & -13.80 & -3.98 \\
\hline & \multirow[t]{2}{*}{ Group C (Class 3) } & Group A (Class 1) & 3.481 & 2.093 & .224 & -1.50 & 8.46 \\
\hline & & Group B (Class 2) & $8.889^{\circ}$ & 2.062 & .000 & 3.98 & 13.80 \\
\hline \multirow[t]{6}{*}{ nasolabial angle, } & \multirow[t]{2}{*}{ Group A (Class 1) } & Group B (Class 2) & .435 & 3.071 & .989 & -6.87 & 7.74 \\
\hline & & Group C(Class 3) & .886 & 3.093 & .956 & -6.47 & 8.24 \\
\hline & \multirow[t]{2}{*}{ Group B (Class 2) } & Group A (Class 1) & .435 & 3.071 & .989 & -7.74 & 6.87 \\
\hline & & Group C (Class 3) & .450 & 3.048 & .988 & -6.80 & 7.70 \\
\hline & Group C (Class 3) & Group A (Class 1) & .886 & 3.093 & .956 & -8.24 & 6.47 \\
\hline & & Group B (Class 2) & .450 & 3.048 & .988 & -7.70 & 6.80 \\
\hline mento labial & Group A (Class 1) & Group B (Class 2) & $-8.760^{\circ}$ & 3.059 & .014 & -16.04 & -1.48 \\
\hline & & Group C (Class 3) & 6.726 & 3.081 & .079 & -.60 & 14.06 \\
\hline & Group B (Class 2) & Group A (Class 1) & $8.760^{\circ}$ & 3.059 & .014 & 1.48 & 16.04 \\
\hline & & Group C(Class 3) & $15.487^{\circ}$ & 3.036 & .000 & 8.26 & 22.71 \\
\hline
\end{tabular}




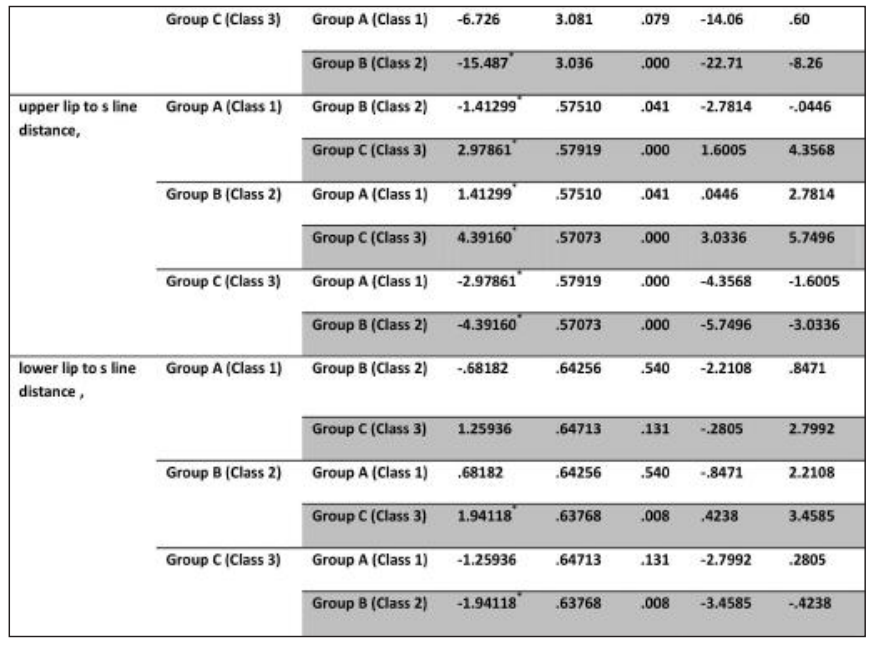

* The mean difference is significant at the 0.05 level.

\section{DISCUSSION}

Long before lateral cephalographs became established Soft tissue profiles were analyzed for diagnostic purposes. When lateral cephalogram was first used for diagnosing and assessing skeletal and dental disharmony by Broadbent ${ }^{13}$ and Hofrath. ${ }^{14}$ this marked the new beginning of orthodontics. Soft tissue diagnostics in cephalometry has proven to be superior from extra oral photography. Many angles, measurement and analysis are given by different authors. Angle of convexity as a measure of profile convexity was given by (Muzj 1956 ${ }^{15}$; Burstone 1958 ${ }^{16}$; Subtelny and Rochester $\left.1959^{17}\right)$. In this study the mean angle of convexity $\left(31.40^{\circ}\right)$ came out to be far more than that given by previous authors $(-11 \pm 4)^{9}$, which depicts a convex profile. This may be because 68 out of 102 patients included in the study were female who have a tendency towards convex profile. As there are no significant differences in angle of convexity value between the three groups, this angle cannot be used to assess skeletal disharmony.

Our mean value for the H.SN angle $\left(62^{\circ}\right)$ came out less than the normal value in previous studies. ${ }^{8-10}$ This also represents the convexity of the facial profile in Asian population. This consistent retrusive profile is a new finding and is not supported by any literature in the past. Rogerio et al analyzed dentofacial characteristics in class I, 2 and 3. H.SN angle in class I group was $67.58^{\circ}$; in class II groups was $59.65^{\circ}$ and $57.58^{\circ}$ in class III group. ${ }^{18}$

$\mathrm{R}$ sukhia et al in their study gave the value of nasolabial angle of $98.6^{\circ}$ in class I and $94.8^{\circ}$ in class II. ${ }^{19}$ Slightly less than nasolabial angle in our study i.e. $100.68^{\circ}$. Dua V, Gupta $\mathrm{s}$ et al did a similar study on Indian population and found out the average value of nasolabial angle was $96.1^{\circ} \pm 9.7^{\circ}$, with males at $96.74^{\circ} \pm 10.89^{\circ}$ and females at $95.64^{\circ} \pm 8.9 .{ }^{20}$
Where as in this present study nasolabial angle for males and females was $104.50^{\circ}$ and $98.76^{\circ}$ respectively. Males have shown higher nasolabial angle than female which is consistent finding in both studies.

A normal mentolabial angle represents a smooth transition from the lower lip to soft tissue chin. A mentolabial angle of approximately $107^{\circ}$ to $118^{\circ}$ was deemed the most attractive, with a range of up to $140^{\circ}$ deemed acceptable by Naini T.F and Coubourn T Martin. ${ }^{21}$ In males this angle came out to be $115.05^{\circ}$ and in females ${ }^{\circ}$ which was less in comparison with Kapadia R et al.(males, $129^{\circ}$ and females $\left.125^{\circ}\right) .^{22}$ Although Kapadia $r$ et al did the study of extra oral profile on photographs rather than cephalograms therefore the reduced value.

When the sagital position of lip in considered, lip prominence is dependent upon the tonicity of lip muscles, inclination of incisors, prominences of jaws, prominence of nose and chin. ${ }^{23}$ Upper and lower lip has been measured with various reference line for e.g. $\mathrm{H}$ line, $\mathrm{E}$ line, $\mathrm{S}$ line. The upper lip to s line value as $2.18 \mathrm{~mm}$ is more than the same value found out by Bokhari Fet al in class II patients only that is $1.96 \mathrm{~mm} .{ }^{24} \mathrm{Joshi} \mathrm{M}$ et al conducted a similar study to ours and found out upper lip to S-line value in class I,II and III groups to be 4.32, 5.35,4.55 $\mathrm{mm}$ respectively, and lower lip to S-line value in all the same classes to be 4.22, 3.47, $5.83 \mathrm{~mm}$ respectively. Upper lip protusiveness in class II group is expressed in both studies. Retrusive lower lip in class III group is expressed from our study only, this finding does not fall with agreement to any previous evidence. Rehan A et al conducted a study in march 2014 comparing soft tissue parameters in class I and class II patients concluded upper lip protrusion in Class I and bilip protrusion in Class II samples with reference to rickets $\mathrm{E}$ line instead of $\mathrm{S}$ line. ${ }^{25}$ The value of nasolabial angle in this study was in agreement to ours i.e more in class 2 than in class 1.

Soft tissue analysis can be used to asses skeletal disproportion but not always does it show the correct malocclusion therefore radiographs and latest imaging techniques have a huge weight age in diagnosis, treatment planning and case based approach.

The inclusion on class III in this study gives it the advantage over other similar studies that only include class I and II $1 .{ }^{9,25}$ The wide variety of variables and gender dimorphism make this a one of a kind soft tissue diagnostic soft tissue study.

\section{CONCLUSION}

We determined that both class I and class II groups had convex profiles, represented by increased angle of convexity. Nasolabial angle was most obtuse in class I and mentolabial 
angle showed the highest value in class II groups. Angle H.SN was highest in class III groups. Upper lip and lower lip to S-line was highest in class II groups. Gender dimorphism was present in all the variables.

\section{CONFLICT OF INTEREST}

None declared

\section{REFERENCES}

1. Sarver DM, Proffit WR, Ackerman JL. Evaluation of facial soft tissues. In: Proffit WR, White RP Jr, Sarver DM, editors. Contemporary treatment of dentofacial de-formity. 4th ed. Elsevier: Mosby; 2008: p. $92-126$.

2. Proffit WR, Fields Jr HW, Sarver DM. Contemporary orthodontics. Elsevier Health Sciences; 2006 Dec 8. Chapter 1,pg 4.6TH Edition.

3. Enlow DH. Facial growth. WB Saunders Company; 1990.Chapter 4, pg7

4. Riedel RA. The relation of maxillary structures to cranium in malocclusion and in normal occlusion. The Angle Orthod. 1952;22: $142-45$.

5. Steiner CC, The use of cephelometrics as an aid to planning and assessing orthodontic treatment: report a case. Am J Orthod.1960;46; 721-36

https://doi.org/10.1016/0002-9416(60)90145-7

6. Burstone CJ, lip posture and its significance in treatment planning, Am J Orthod, 1967:53

https://doi.org/10.1016/0002-9416(67)90022-X

7. Ricketts RM. Planning treatment on the basis of facial pattern and an estimate of its growth, Angle Orthod 1957:27

8. Holdaway RA, Merrifield LL. A soft-tissue cephalometric analysis and its use in orthodontic treatment planning. Part I. Am J Orthod. $1983 ; 84: 1-28$

https://doi.org/10.1016/0002-9416(83)90144-6

9. Downs WB. Análises do perfil dentofacial. Angle Orthod. 1956;26:191-212.

10. Merifield LL. Profile Line as an Aid in Critically Evaluating Facial Esthitics. Am. J. Orthod. 1966;52:804.

https://doi.org/10.1016/0002-9416(66)90250-8

11. Scheideman GB, Bell WH, Legan HL, Finn RA, Reisch JS. Cephalometric analysis of dentofacial normals. AM J Orthod. 1980;78:404-20.

https://doi.org/10.1016/0002-9416(80)90021-4

12. Nguyen DD, Turley PK. Changes in the Caucasian male facial profile as depicted in fashion magazines during the twentieth century. Am J Orthod Dentofacial Orthop. 1998;114:208-17.

https://doi.org/10.1053/od.1998.v114.a86137
13. Broadbent BH. A new X-ray technique and its application to orthodontia: the introduction of cephalometric radiography. The Angle Orthodontist. 1981;51:93-114.

14. Hofrath H. Die bedeutung der röntgenfern-und abstandsaufnahme für die diagnostik der kieferanomalien. Fortschritte der Orthodontik in Theorie und Praxis. 1931;1:232-58.

https://doi.org/10.1007/BF02002578

15. Muzj E. Biometric correlations among organs of the facial profile: A possible solution to the present crisis in orthodontics. Am J Orthod. 1956;42:827-57.

https://doi.org/10.1016/0002-9416(56)90090-2

16. Burstone CJ . The integumental profile, American Journal of Orthodontics. 1958;44:1-25

https://doi.org/10.1016/S0002-9416(58)90178-7

17. Subtelny JD, Rochester NY .A longitudinal study of soft tissue facial structures and their profile characteristics, defined in relation to underlying skeletal structures , American Journal of Orthodontics, 1959;45:481-507

https://doi.org/10.1016/0002-9416(59)90014-4

18. Santos RL, Ruellas AC. Dentofacial characteristics of patients with Angle Class I and Class II malocclusions. Dental Press J Orthod. 2012;17:46-e1.

https://doi.org/10.1590/S2176-94512012000200010

19. Sukhia R, Ghandhi D. Skeletal class $1 \& 2$ malocclusion evaluation in JMDC Orthodontic Patients. Pak Oral Dent J, 26(2)

20. VinayDua, Shilpa Gupta, and Chanjyot Singh, Evaluation of the nasolabial angle in the Indian population Contemp Clin Dent. 2010; 1:79-82.

https://doi.org/10.4103/0976-237X.68595

21. Farhad B. Naini, Martyn T. Cobourne, Umberto Garagiola, Mentolabial angle and aesthetics: a quantitative investigation of idealized and normative values MaxillofacPlastReconstr Surg. 2017; 39:4.

https://doi.org/10.1186/s40902-017-0102-8

22. Kapadia R, Gadhia D and Diora S. An Estimation of Mento-Labial Angle on Standardized Digital Photographs in Gujarati Population A Cross Sectional Study. Int J Sci Res Pub. 2013:3(8)

23. Ying-ying SU, Chun-ling WA, Dong-xu LI, Ren-ping DO, Hong LI. Influence of chin prominence on anterior-posterior lip positions of facial profile. Shanghai J Stomatol. 2008.

24. Bokhari F, Asad S, Amin F. Cephalometric Assessment of Lips in Skeletal Class II Patients by Steinerâ ${ }^{\mathrm{TM}}$ s Line. Annals of King Edward Medi Uni. 2013;19:11.

25. Rehan A, Iqbal R, Ayub A, Ahmed I. Soft tissue analysis in class I and class II skeletal malocclusions in patients reporting to department of Orthodontics, Khyber College of Dentistry, Peshawar. Pak Oral \& Dent J. 2014;34:87-90. 